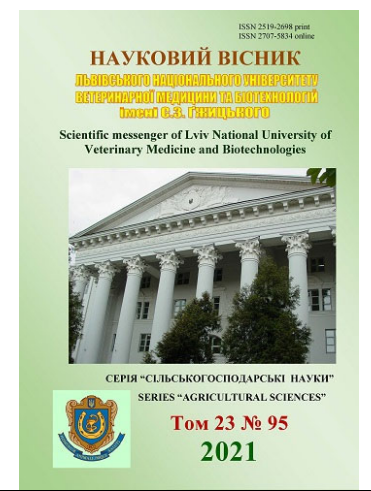

Науковий вісник Дьвівського національного університету ветеринарної медицини та біотехнологій імені С.3. Гжицького. Серія: Сільськогосподарські науки

\author{
Scientific Messenger of Lviv National University \\ of Veterinary Medicine and Biotechnologies. \\ Series: Agricultural sciences
}

ISSN 2519-2698 print ISSN 2707-5834 online doi: 10.32718/nvlvet-a9526

https://nvlvet.com.ua/index.php/agriculture

UDC 636.034:591.5

\title{
Feed behavior and milk productivity in cows of different fattening
}

\author{
T. V. Polishchuk, V. V. Bondarenko \\ Vinnytsia National Agrarian University, Vinnytsia, Ukraine
}

Article info

Received 25.07.2021

Received in revised form 29.08.2021

Accepted 30.08.2021

Vinnytsia National Agrarian University, Soniachna Str., 3 Vinnytsia, 21008, Ukraine. Tel.: +38-096-964-30-87 E-mail:vladuslavavs@gmail.com
Polishchuk, T. V., \& Bondarenko, V. V. (2021). Feed behavior and milk productivity in cows of different fattening. Scientific Messenger of Lviv National University of Veterinary Medicine and Biotechnologies. Series: Agricultural sciences, 23(95), 172-180. doi: 10.32718/nvlvet-a9526

The results of feed behavior and milk productivity in the cows of Ukrainian black-speckled dairy breed of different fattening of the first and second lactations from the first month to the end of lactation are given. The analysis of the herd showed that the highest milk productivity in cows of the first lactation was found in the group of fattening from 3 to 4 points, which was by $9.2 \%(P \geq 0.99)$ higher, compared to the group of cows with fattening 4 points and more. The milk yield in cows of the second lactation with fattening from 3 to 4 points exceeded the milk yield of cows with fattening 4 points and more by $12.9 \%(P \geq 0.95)$. The content of fat and protein in milk was higher in the cows with higher fattening, compared to the cows with lower fattening. The highest average daily milk yield was found in cows of the first lactation with fattening from 3 to 4 points. Depending on the month, it was by 5.5-11.7\% (P $\geq 0.95-P \geq 0.999)$ higher, compared to the cows with fattening 4 points and more, while it was by $6.9-10.0 \%(P \geq 0.95-P \geq 0.999)$ higher in cows of the second lactation. The gestation period of cows has a significant effect on the reduction of milk yield. The milk yield of cows in connection with the term of their gestation are reduced by $0.1 \mathrm{~kg}$ per day during the second month after insemination, by $0.2 \mathrm{~kg}$ per day during the third month, by $0.3 \mathrm{~kg}$ per day during the fourth month, by $0.6 \mathrm{~kg}$ per day during the fifth month, by $1.0 \mathrm{~kg}$ per day during the sixth month, by $1.7 \mathrm{~kg}$ per day during the seventh month and by $2.8 \mathrm{~kg}$ per day during the eighth month. The analysis of the dynamics of monthly milk yield shows that lactation curves of cows increase from the first day of lactation to its peak, which occurs in the $2^{\text {nd }}-4^{\text {th }}$ month after calving. The lactation curve in the cows with fattening from 3 to 4 points has a higher peak in the $2^{\text {nd }}-3^{d}$ month of lactation, compared to the cows with higher (more than 4 points) fattening. The animals of all groups, except for cows of the second lactation (with fattening 4 and more points) showed the maximum productivity in the $2^{\text {nd }}-3^{d}$ month of lactation; then the lactation curve decreased with different intensity. The index of constancy of lactation and the index of falling milk yield are the important indicators that characterize the stability of lactation curves. The constancy of lactation curves having been determined by I. Johansson-Hansson index was higher in the cows with fattening 4 and more points, compared to the indicator of the cows with fattening from 3 to 4 points. The studies of behavioral reactions have shown that the animals of the first lactation with an average (from 3 to 4 points) fattening consume feed during 208.5 minutes, which is by 17 minutes $(P \geq 0.999)$ longer than the animals with higher average fattening, and by 14.5 minutes $(P \geq 0.99)$ longer than the animals of the second lactation.

Key words: fattening, feed behavior, milk productivity, lactation curve, lactation, milk yield.

\section{Кормова поведінка та молочна продуктивність корів різної вгодованості}

\author{
Т. В. Поліщук, В. В. Бондаренко
}

Вінницький національний аграрний університет, м. Вінниця, Украӥна

\footnotetext{
Наведено результати кормової поведінки та молочної продуктивнісоті корів украӥнської чорно-рябої молочної породи різної вгодованості першої та другої лактацій, починаючи з першого місяия $і$ до закінчення лактаиії. Аналіз стада показав, що найвища

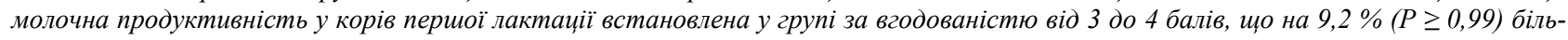
ше, проти показника групи корів із вгодованістю 4 бали і більше. У корів другої лактації надої групи із вгодованістю від 3 до 4
} 
балів перевищували надої корів із вгодованістю 4 бали і більше на 12,9\% (P $\geq 0,95)$. У корів із вищою вгодованістю вміст жиру $i$ білку в молочі, супроти корів нижчої вгодованості, був вищий. Найвищі середньодобові надої корів першої лактацій встановлено у групах за вгодованістю від 3-х до 4-х балів, шзо залежно від місячя на 5,5-11,7\% (P $\geq 0,95-P \geq 0,999)$ більше, проти показника групи корів із вгодованістю 4 бали і вище, корів другої лактації-на 6,9-10,0\% (P $\geq 0,95-P \geq 0,999)$ відповідно. Значний вплив на зниження надоїв має період тільності корів. Так, надої корів у зв'язку з терміном їхньої тільності знижуються упродовж другого місячя після осіменіння на 0,1 кг за добу, упродовж третього місячя - на 0,2, упродовж четвертого - на 0,3, п'ятого - на 0,6, шостого - на 1,0, сьомого на 1,7 і упродовж восьмого місяия - на 2,8 кг за добу. Аналіз динаміки щчомісячних надоӥв показує, щчо лактаційні криві корів зростають з першого дня лактаџії до ї̈ піку, який настає на 2-му - 4-му місяці після отелення. У корів $з$ вгодованістю від 3-х до 4-х балів лактаџійна крива має вищий пік на 2-3 міс. лактації, проти показника корів з вищою (понад 4 бали) вгодованістю. Максимальну продуктивність тварини всіх груп, окрім корів другої лактації (4 і більше балів за вгодованістю) проявляли на 2-3-му місящі лактації, а потім лактаційна крива спадала з різною інтенсивністю. Важливими показниками, щцо характеризують стійкість лактаційних кривих є показник індексу постійності лактації та індекс падіння надою. Постійність лактаційних кривих визначена за індексом І. Іоганссона-Ханссона була вищою у корів, вгодованість яких була 4 і більше балів, супроти показника корів, яких оцінено від 3 до 4 балів. Дослідження поведінкових реакцій показали, щзо найдовще споживають корм тварини периої лактації з середньою (від 3-х до 4-х балів) вгодованістю - 208,5 хв, шуо на 17 хв (P $\geq 0,999)$ довие, ніж твари-

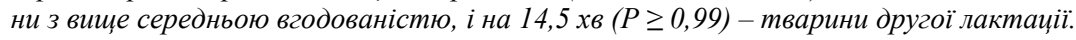

Ключові слова: вгодованість, кормова поведінка, молочна продуктивність, лактаційна крива, лактація, надої.

\section{Вступ}

Одним зі стратегічних напрямів розвитку молочного скотарства в Україні $\epsilon$ широке застосування енергоресурсоощадних технологій, які базуються на високому рівні автоматизації. Однак практика показує, що за таких технологій не завжди вдається досягти високих показників молочної продуктивності у поєднанні з поведінковими реакціями.

На сьогодні в Україні розводять велику рогату худобу різних молочних порід з високим потенціалом як продуктивних, так і відтворювальних ознак (Minviel \& Latruffe, 2017; Iaremchuk \& Hotsuliak, 2019).

Разом $з$ цим на практиці не завжди вдається реалізувати генетичний потенціал продуктивності, що значною мірою залежить від технологічних факторів. В умовах індивідуального догляду за худобою, у разі забезпечення необхідною кількістю і якістю кормів, легше реалізувати генетичний потенціал тварин, але за групового утримання виникають певні проблеми. Так, на сучасних фермах, де утримують худобу, важливі й необхідні нові селекційні та технологічні рішення для забезпечення успішної експлуатації корів 3 максимальним проявом їхніх генетичних задатків.

Рівень молочної продуктивності корів, їх пристосованості до інтенсивної технології, стан здоров'я і довголіття значною мірою залежать не тільки від конституції й екстер'єру, а й від стану вгодованості тварин у різні періоди лактаційної діяльності. У молочному скотарстві США, Канади, Австралії та переважній більшості країн Європи надають великого значення ступеню вгодованості тварин. Встановлено залежність між цією ознакою 3 відтворювальною здатністю та подальшою продуктивністю (Shcherbatyi et al., 2017; Cherniavska, 2018).

Актуальність теми. Дослідження ряду зарубіжних вчених, які були проведені на коровах, показують, що за рахунок регулювання (управління) вгодованістю корів у різні періоди їхньої життєдіяльності можна досягти підвищення продуктивного рівня, відтворення й тривалості використання.

Переважна більшість вчених при оцінці годівлі та утримання молочної худоби приділяють значну увагу типу приміщень, у яких утримують тварин, умовам середовища, стресостійкості, ветеринарно-санітарним вимогам, живій масі корів, при цьому менш вивченим $\epsilon$ питання їхньої вгодованості (Chernenko et al., 2018; Mylostyvyi et al., 2019; Mylostyvyi \& Chernenko, 2019).

Оцінка вгодованості корів є прямим відображенням ефективності управління годівлею на фермі та дозволяє оцінити, як відстежуються кондиції та стан корів на різних стадіях лактації (Tkachuk et al., 2016). Періодичне визначення вгодованості дозволяє порівнювати наявний стан корів та корегувати процес годівлі в той чи інший бік за розробленими рекомендаціями (Dubin \& Volenko, 2005; Havrylenko et al., 1994).

Відомо, що рівень вгодованості корови перед отеленням має прямий вплив на потенційні ускладнення, що можуть виникнути перед, під час або після отелення, та молочну продуктивність і репродуктивну ефективність перед майбутньою лактацією. Під вгодованістю слід розуміти ступінь розвитку м'язової тканини i відкладень депонованого внутрішнього підшкірного жиру. Водночас вгодованість є показником кількості засвоєного жиру і енергії твариною (Petrenko, 2003).

Рівень вгодованості корів протягом лактації значною мірою залежить від таких факторів, як породна приналежність, технологія утримання, годівля, елементи поведінки. Дослідження, які були проведені рядом зарубіжних вчених на тваринах голштинської породи, показують, що за рахунок регулювання (управління) вгодованістю корів у різні фізіологічні періоди можна досягти підвищення продуктивних і відтворних ознак. При цьому найраціональніше використовуються кормові ресурси, котрі становлять найбільшу складову в собівартості виробництва продукції (Iasevin, 2011).

На думку Edmonson A. J. et al. (Edmonson et al., 1989), найбільш оптимальним у сухостійний період $€$ рівень вгодованості корів в межах 3-3,5 бала (за 5бальною шкалою). Це означає, що таку вгодованість тварина набуває в період пізньої стадії лактації. Тварини повинні не збільшити і не втратити цей стан вгодованості в сухостійний період. Корови, котрі втрачають вгодованість протягом сухостійного періоду, мають підвищений ризик мертвонароджень.

Проте іншої думки Г. Більченко (Bilchenko, 2011), який вважає, що оптимальною в цей період $є$ вгодованість до 3 балів. При цьому від початку сухостійного 
періоду до осіменіння втрата вгодованості не повинна перевищувати 1 бал.

Низький стан вгодованості перед отеленням знижує репродуктивну функцію, збільшуючи сервісперіод. Рівень вгодованості менше ніж 2,25 бала зазвичай знижує репродуктивну функцію, подовжує термін до першого приходу в охоту і відповідно сервіс-періоду (Berry et al., 2003).

Дослідники з університету штату Вісконсин встановили, що корови 3 рівнем вгодованості менше ніж 3 бали під час отелення не завжди мають достатній запас енергії (жиру), щоб досягти піку надоїв або підтримувати високий їх рівень. При цьому у тварин, рівень вгодованості яких становив 4 бали і вище, спостерігали зниження апетиту і зменшення споживання сухої речовини корму та надмірне накопичення жиру, що призводило до проблем в обміні речовин.

Вважається, що впродовж перших 80 днів лактації корови в середньому повинні мати вгодованість на рівні 2,5-3 бали. Максимально допустимі втрати вгодованості в цей період не повинні перевищувати 1 бал (Tkachuk et al., 2016; Minviel \& Latruffe, 2017; Shcherbatyi et al., 2017).

Рівень вгодованості повинен підвищуватися після 80-90-го днів лактації, але слід контролювати, щоб він не перевищував 4 бали в кінці періоду лактації. Оптимальним вважається, коли в період після 100 днів лактації вгодованість підвищується на 0,25 бала кожні 30 днів у другій половині лактації та кожні 50 днів у заключний період лактації до запуску (Podobed et al., 2009).

Також $є$ повідомлення про вплив вгодованості на стан кінцівок та молочної залози. У корів, що мали вгодованість у сухостійний період 4 бали і більше, в сім разів частіше виникали проблеми із кінцівками в подальшу лактацію порівняно $з$ тваринами, вгодованість яких становила до 4-х балів в цей період. Інші дослідження, в котрих вивчали вплив вгодованості перед отеленням та на початку лактації на кульгавість, було встановлено, що тварини з вгодованістю менше 3-х балів перед отеленням мають ризик захворювань кінцівок під час наступної лактації. Однак 3 даних досліджень не зрозуміло, чи це низька вгодованість викликає кульгавість, чи кульгавість спричинює зниження вгодованості через зменшення споживання сухої речовини (Herlihy et al., 2011).

За умов різних варіантів безприв'язного утримання забезпечення вгодованості корів у сухостійному періоді на рівні від 3 до 4-х балів дає можливість отримати за наступну лактацію на 8,3-22,5 \% (585,51416,81 грн) більший прибуток порівняно 3 коровами більш високої вгодованості (Borshch, 2016).

Пік кормової активності у корів за добровільної системи доїння спостерігається після роздавання кормосумішей - вранці та після обіду. У корів з середньою вгодованістю і найвищими добовими надоями тривалість споживання кормів найвища (Borshch et al., 2016).

Успіх технології виробництва молока багато в чому залежить від того, як правильно використовують тварин з урахуванням їхніх біологічних особливостей, у тому числі й поведінки. Відомо, що генетичний потенціал продуктивності молочної худоби в Україні перебуває в межах 7000-8000 кг, а в ряді зон 9000-10000 кг і вище. Однак фактична продуктивність корів у середньому нижча на 20-30 \% через недостатню відповідність менеджменту, кормової бази і технології утримання біологічним потребам тварин.

Класики біологічної та зоотехнічної науки вказували, що знання про поведінку тварин - необхідна умова для їх одомашнення, розведення та належного утримання, що забезпечує отримання високої продуктивності тварин і підвищення продуктивності праці в тваринництві.

Активна діяльність худоби характеризується щоденними повторюваними ритмами з невеликими змінами, які можуть залежати від природних умов, пори року та фізіологічного стану тварини. Головними параметрами поведінки молочної худоби $є$ поїдання кормів і жування жуйки, відпочинок, забезпечення соціальних і репродуктивних потреб. Поряд з іншими фізіологічними процесами для годівлі корів велике значення має рухова діяльність, спрямована на здійснення контакту тварини 3 кормовими подразниками i поїдання корму. Маючи різну потребу в кормах тварини різних статево-вікових груп суттєво відрізняються за основними елементами поведінки. Знання цих відмінностей і використання їх на практиці дозволяє підвищити продуктивність тварин (Plotnikov \& Chuchunov, 2007; Lukhtai, 2009).

Тривалість споживання кормів залежить від ситості тварини, смаку й вигляду корму і насамперед від кількості і якості сухого корму та від того, напоєна тварина чи ні. Споживання сухої речовини корму переважно залежить від розмірів тварини, відношення об'ємних і концентрованих кормів, рівня молочної продуктивності, а також швидкості перетравності корму (Shkurko, 2009; Tarasova, 2017).

Отже, проведення досліджень 3 вивчення динаміки вгодованості корів української чорно-рябої молочної породи та ії впливу на продуктивність $є$ актуальним.

Метою досліджень $є$ вивчення впливу вгодованості корів української чорно-рябої молочної породи на продуктивність і кормову поведінку корів.

\section{Матеріал і методи досліджень}

Дослідження проводились у Товаристві з обмеженою відповідальністю “Сільськогосподарське орендне підприємство “Михайлівське”, яке знаходиться в центральній частині Вінницького району в селі Михайлівка Вінницької області. Розміщене господарство у 15 км від обласного центру міста Вінниці у вигідних умовах стосовно закупівлі та реалізації сільськогосподарської продукції. Господарство спеціалізується на вирощуванні зернових та зернобобових культур, розведенні великої рогатої худоби.

ТОВ “СОП "Михайлівське" - ферма з середньорічним поголів'ям 504 корів української чорно-рябої молочної породи. На фермі впроваджено стійлововигульну систему утримання, прив'язний спосіб утримання худоби, триразове доїння. Середньорічний надій на корову становить 5286 кг молока. У господарстві застосовується цілорічна однотипна годівля 
корів загальнозмішаними раціонами із годівниць у приміщенні.

Дослідження проводили на коровах української чорно-рябої молочної породи першої та другої лактацій, починаючи з першого місяця лактації і до закінчення лактації.

Корови утримувались за стійлово-вигульною системою на однаковому рівні, типі годівлі та структурі раціонів.

Для проведення дослідження було сформовано дослідні групи з корів першої та другої лактацій української чорно-рябої молочної породи згідно зі схемою досліду (табл. 1).

\section{Таблиця 1}

Схема досліду

\begin{tabular}{ccc}
\hline \multirow{2}{*}{ Лактація } & $\begin{array}{c}\text { Група за вгодованістю, } \\
\text { балів }\end{array}$ & $\begin{array}{c}\text { Кількість } \\
\text { голів }(\mathrm{n})\end{array}$ \\
\hline \multirow{2}{*}{1} & від 3-х до 4-х & 28 \\
& 4 i більше & 18 \\
\hline \multirow{2}{*}{2} & від 3-х до 4-х & 33 \\
& 4 i більше & 26 \\
\hline
\end{tabular}

Вгодованість корів визначали перед отеленням окомірно та за допомогою щупів за 5-бальною шкалою, запропонованою Edmondson A. J. et al. (Edmonson et al., 1989).
Молочну продуктивність (надій за лактацію, середньодобовий надій, вміст жиру в молоці, кількість молочного жиру, вміст білка, кількість молочного білка) визначали за даними контрольних доїнь та комп'ютерного обліку.

Поведінку та реакцію корів вивчали протягом 720 хвилин (за вийнятком часу, затраченого на доїння корів - 180 хвилин) за методикою візуальних спостережень за допомогою азбуки елементів і актів поведінки відповідно до методики М. В. Зубця (1996) за такими ознаками, як тривалість споживання корму, положення стоячи (у тому числі жуйки), положення лежачи (у тому числі жуйки), жуйки, активного руху.

Біометричну обробку отриманих результатів здійснювали методом варіаційної статистики за методикою М. О. Плохинського (1969).

\section{Результати та їх обговорення}

На початку досліджень нами було вивчено вгодованість корів першої та другої лактацій. У ТОВ “СОП “Михайлівське” серед корів першої лактації найбільшу частку становили корови $з$ середньою вгодованістю (від 3-х до 4-х балів) і складала вона 25 голів (64\%), а корів 3 вищесередньою вгодованістю (4 i більше балів) - 14 голів (36 \%) (табл. 2).

\section{Таблиця 2}

Показники живої маси корів різної вгодованості

\begin{tabular}{|c|c|c|c|c|}
\hline \multirow{3}{*}{ Місяць лактації } & \multicolumn{2}{|c|}{ Перша лактація, $\mathrm{n}=39$} & \multicolumn{2}{|c|}{ Друга лактація, $\mathrm{n}=42$} \\
\hline & \multicolumn{2}{|c|}{ Група корів за вгодованістю, балів } & \multicolumn{2}{|c|}{ Група корів за вгодованістю, балів } \\
\hline & від 3 до 4 & 4 і більше & від 3 до 4 & 4 і більше \\
\hline $\mathrm{n}$ & 25 & 14 & 29 & 13 \\
\hline Жива маса, кг & $498 \pm 3,6$ & $523 \pm 4,1 * * *$ & $538 \pm 3,7$ & $552 \pm 3,2 * *$ \\
\hline
\end{tabular}

Примітки: ** $\mathrm{P}>0,99 ; * * * \mathrm{P}<0,999$ супроти групи корів середньої вгодованості

Серед корів другої лактації найбільшу частку становили корови з середньою вгодованістю (від 3-х до 4-х балів) і складала 29 голів (69\%), а корів з вищесередньою вгодованістю (4 і більше балів) - 13 голів $(31 \%)$.

Корови першої лактації за вгодованістю 4 бали і вище, проти корів за вгодованості від 3-х до 4-х балів, відрізнялися вищим показником живої маси на 5,0 \% ( $\mathrm{P} \geq 0,999)$, другої лактації - на 2,5 \% (P $\geq 0,95)$ відповідно.

Дослідження продуктивності корів показали, що корови другої лактації мали вищі надої за лактацію, проти корів першої лактації (табл. 3).

\section{Таблиця 3}

Показники продуктивності корів різної вгодованості

\begin{tabular}{|c|c|c|c|c|}
\hline \multirow{3}{*}{ Показник } & \multicolumn{2}{|c|}{ Перша лактація, $\mathrm{n}=39$} & \multicolumn{2}{|c|}{ Друга лактація, $\mathrm{n}=42$} \\
\hline & \multicolumn{2}{|c|}{ Група корів за вгодованістю, балів } & \multicolumn{2}{|c|}{ Група корів за вгодованістю, балів } \\
\hline & від 3 до 4 & 4 i більше & від 3 до 4 & 4 i більше \\
\hline $\mathrm{n}$ & 25 & 14 & 29 & 13 \\
\hline Надій за лактацію, кг & $4941 \pm 274,2$ & $4566 \pm 197,2 * *$ & $5525 \pm 234,1$ & $4812 \pm 212,9 *$ \\
\hline Середньодобовий надій, кг & $18,2 \pm 0,58$ & $17,1 \pm 0,49$ & $18,7 \pm 0,50$ & $17,2 \pm 0,42 *$ \\
\hline Вміст жиру в молоці, \% & $3,69 \pm 0,02$ & $3,74 \pm 0,01^{*}$ & $3,70 \pm 0,01$ & $3,77 \pm 0,01 * * *$ \\
\hline Вміст білка в молоці, \% & $3,21 \pm 0,01$ & $3,29 \pm 0,01 * * *$ & $3,25 \pm 0,01$ & $3,30 \pm 0,02 *$ \\
\hline
\end{tabular}

Примітки: * $\mathrm{P}>0,95 ; * * \mathrm{P}>0,99 ; * * * \mathrm{P}<0,999$ супроти групи корів середньої вгодованості

Найвища молочна продуктивність у корів першої лактації встановлена у групі за вгодованістю від 3 до 4 балів, що на 9,2 \% (P $\geq 0,99)$ більше проти показника групи корів із вгодованістю 4 бали і більше. У корів другої лактації надої групи із вгодованістю від 3-х до 4-х балів перевищували надої корів із вгодованістю 
4 бали і більше на $12,9 \%(\mathrm{P} \geq 0,95)$.

Корови першої лактації за вгодованістю від 3-х до 4-х балів відрізнялися вищими середньодобовими надоями на 6,0 \%, проте вірогідної різниці не встановлено. Добові надої корів із вгодованістю 4 бали і більше були меншими проти показника групи корів із вгодованістю від 3 до 4 балів, на $8 \%(\mathrm{P} \geq 0,95)$.

Молоко корів, оцінених за вгодованістю 4 бали i вище проти ровесниць вгодованості від 3-х до 4-х балів, характеризувалося вищим вмістом жиру за першу лактацію на $0,05 \%$ (P $\geq 0,95)$, вмістом білка на $0,08 \%$ (P $\geq 0,999)$, за другу лактацію на $0,07 \%$ (P $\geq$ $0,999)$ і $0,05 \%(\mathrm{P} \geq 0,95)$ відповідно.

Дослідженнями встановлена тенденція до підвищення молочної продуктивності корів 3 нижчою (від 3-х до 4-х балів) вгодованістю проти показників корів, вгодованість яких була на рівні від 4-х балів і вище. У корів із вищою вгодованістю вміст жиру і білку в молоці супроти корів нижчої вгодованості, був вищий.

Значний вплив на зниження надоїв має період тільності корів. Так, надої корів у зв'язку з терміном їхної тільності знижуються упродовж другого місяця після осіменіння на 0,1 кг за добу, упродовж третього місяця - на 0,2, упродовж четвертого - на 0,3 , п'ятого - на 0,6 , шостого - на 1,0 , сьомого на 1,7 і упродовж восьмого місяця - на 2,8 кг за добу.

Найвищі середньодобові надої корів першої лактацій встановлено у групах за вгодованістю від 3-х до 4-х балів, що залежно від місяця на 5,5-11,7 \% (P $\geq$ $0,95-\mathrm{P} \geq 0,999)$ більше проти показника групи корів із вгодованістю 4 бали і вище, корів другої лактації на $6,9-10,0 \%(\mathrm{P} \geq 0,95-\mathrm{P} \geq 0,999)$ відповідно (табл. 4).

\section{Таблиця 4}

Середньодобовий надій корів різної вгодованості впродовж лактації

\begin{tabular}{ccccc}
\hline \multirow{2}{*}{$\begin{array}{c}\text { Місяць } \\
\text { лактації }\end{array}$} & \multicolumn{2}{c}{ Перша лактація, $\mathrm{n}=39$} & \multicolumn{2}{c}{ Друга лактація, $\mathrm{n}=42$} \\
\cline { 2 - 5 } & \multicolumn{2}{c}{ Група корів за вгодованістю, балів } & Група корів за вгодованістю, балів \\
\hline від 3 до 4 & 25 & 14 & від 3 до 4 & 4 і більше \\
\hline $\mathrm{n}$ & $18,4 \pm 0,41$ & $17,8 \pm 0,22$ & 29 & 13 \\
2 & $20,8 \pm 0,47$ & $19,2 \pm 0,28^{* *}$ & $22,9 \pm 0,51$ & $22,6 \pm 0,29^{* * *}$ \\
3 & $22,0 \pm 0,38$ & $22,5 \pm 0,25$ & $24,6 \pm 0,56$ & $23,1 \pm 0,38^{* * *}$ \\
4 & $21,9 \pm 0,33$ & $21,3 \pm 0,23$ & $22,5 \pm 0,55$ & $21,1 \pm 0,25$ \\
5 & $20,9 \pm 0,32$ & $19,1 \pm 0,23^{* * *}$ & $20,7 \pm 0,43$ & $19,2 \pm 0,26^{* *}$ \\
6 & $18,2 \pm 0,33$ & $17,2 \pm 0,20^{*}$ & $18,8 \pm 0,31$ & $17,6 \pm 0,32^{*}$ \\
7 & $16,9 \pm 0,39$ & $15,6 \pm 0,21^{* *}$ & $17,5 \pm 0,26$ & $16,0 \pm 0,35^{* *}$ \\
8 & $15,8 \pm 0,31$ & $14,4 \pm 0,22^{* *}$ & $16,2 \pm 0,21$ & $15,4 \pm 0,28^{*}$ \\
9 & $14,1 \pm 0,23$ & $13,5 \pm 0,23$ & $15,6 \pm 0,27$ & $14,3 \pm 0,18^{* * *}$ \\
10 & $12,8 \pm 0,26$ & $11,3 \pm 0,19^{* * *}$ & $13,4 \pm 0,26$ & $12,1 \pm 0,25^{* *}$ \\
\hline
\end{tabular}

Примітки: * $\mathrm{P}>0,95 ; * * \mathrm{P}>0,99 ; * * * \mathrm{P}<0,999$ супроти групи корів середньої вгодованості

Графічне зображення динаміки надоїв корів упродовж лактації називають лактаційною кривою. За формою лактаційної кривої можна зробити висновок про відповідність умов годівлі, утримання й експлуатації фізіологічним потребам організму в певні періоди лактації.

Аналіз динаміки щомісячних надоїв показує, що лактаційні криві корів зростають 3 першого дня лактації до ії піку, який настає на 2-му - 4-му місяці після отелення. У корів $з$ вгодованістю від 3-х до 4-х балів лактаційна крива має вищий пік на 2-3 міс. лактації проти показника корів 3 вищою (понад 4 бали) вгодованістю (рис. 1).

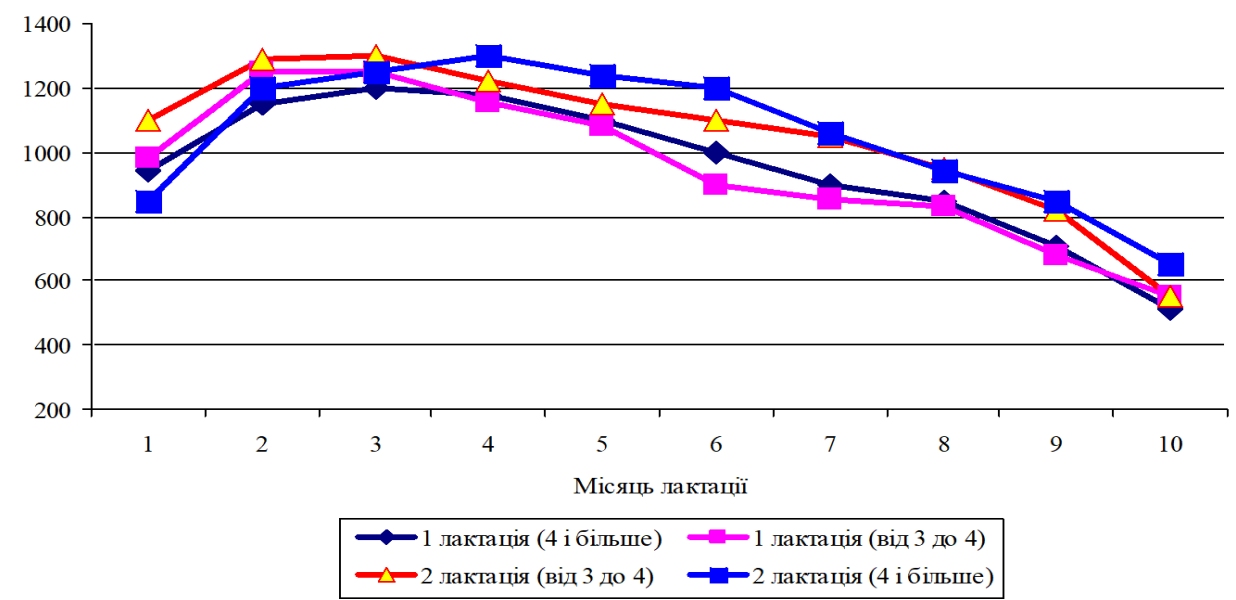

Рис. 1. Лактаційні криві корів різної вгодованості 
Вивчення лактаційних кривих корів різної вгодованості свідчить, що максимальну продуктивність тварини всіх груп, окрім корів другої лактації (4 i більше балів за вгодованістю) проявляли на 2-3-му місяці лактації, а потім лактаційна крива спадала 3 різною інтенсивністю.

При цьому найвищі місячні надої мали корови другої лактації, у подальшому надої поступово щомісячно знижувалися з різким падінням після шостого місяця лактації. У даному випадку тварини спочатку підвищують секрецію молока завдяки фізіологічному максимуму. Лактаційна крива характеризується високим індексом падіння надою, що свідчить про те, що умови утримання, годівлі та експлуатації тварин даної породи забезпечують найвищу продуктивність. Однак корови, вгодованість яких оцінено в 4 і більше балів, за таких умов знижують продуктивність за дещо більш інтенсивного спадання 3 третього-четвертого місяця лактації.

Лактаційна крива корів першої лактації та вгодованості від 3-х до 4-х балів має найвищий надій після отелення і характеризується різким зростанням надоїв до другого місяця лактації, різким спаданням 3 третього місяця до шостого, стабільним зниженням надоїв у наступні місяці до кінця лактації. Крива корів, яких оцінили в 4 і більше балів, характеризується поступовим підвищенням до третього-четвертого місяця та поступовим зниженням до ії закінчення.

Крива надоїв у корів другої лактації характеризувалася різким зростанням до піку лактації з різким зниженням до певних місяців і подальшим поступо- вим зниженням до іiї закінчення.

Лактаційна крива корів другої лактації, яких оцінено від 3-х до 4-х балів за вгодованістю, зросла до другого місяця лактації та різко спадала до сьомого, а надалі зафіксовано поступове зниження. Крива корів, яких оцінено у 4 бали і вище, характеризується різким зростанням надоїв до другого місяця лактації, поступовим спаданням до шостого і стабільним зниженням надоїв у наступні місяці до кінця лактації.

Отже, формування лактаційних кривих дозволяє встановити позитивний або негативний вплив на молочну продуктивність вгодованості корів. За перебігом лактації корів української чорно-рябої молочної породи, яких оцінено у 4 і більше балів за вгодованістю, можна зарахувати до типу корів з високою і сталою продуктивністю та рівномірним перебігом лактації. Корів, що оцінили за вгодованістю від 3-х до 4-х балів, до тих, які відразу після отелення проявляють високу продуктивність, що згодом різко знижується, лактаційна крива після короткочасного руху вгору швидко спадає.

Важливими показниками, що характеризують стійкість лактаційних кривих, $є$ показник індексу постійності лактації та індекс падіння надою.

За постійністю лактаційних кривих вірогідної різниці між групами не встановлено (табл. 5). Постійність лактаційних кривих, визначена за індексом I. Іоганссона-Ханссона, була вищою у корів, вгодованість яких була 4 і більше балів супроти показника корів, яких оцінено від 3-х до 4-х балів.

\section{Таблиця 5}

Показники постійності лактацій корів різної вгодованості

\begin{tabular}{ccccc}
\hline & \multicolumn{2}{c}{ Перша лактація, $\mathrm{n}=39$} & \multicolumn{2}{c}{ Друга лактація, $\mathrm{n}=42$} \\
\cline { 2 - 5 } Показник & $\begin{array}{c}\text { Група корів за вгодованістю, } \\
\text { балів }\end{array}$ & $\begin{array}{c}\text { Група корів за вгодованістю, } \\
\text { балів }\end{array}$ \\
\cline { 2 - 5 } & від 3 до 4 & 4 i більше & від 3 до 4 & 4 і більше \\
\hline n & 25 & 14 & 29 & 13 \\
Індекс постійності лактації І. Іоганссона- А. Ханссона, \% & $85,4 \pm 2,42$ & $90,8 \pm 2,88$ & $89,3 \pm 1,99$ & $92,5 \pm 2,54$ \\
Індекс спадання надою до 7-ми міс., \% & $79,5 \pm 1,86$ & $82,4 \pm 0,68$ & $81,5 \pm 1,54$ & $85,6 \pm 1,97$ \\
\hline
\end{tabular}

Лактаційні криві характеризуються високим індексом падіння надою. Отже, умови утримання, годівлі і експлуатації даної технології утримання забезпечують найвищу продуктивність корів-первісток. Однак корови 3 вгодованістю 4 бали і більше за таких умов знижують продуктивність за дещо більш інтенсивного спадання лактації.

Відпочинок, годівля та доїння корів, які утримувались у дослідному господарстві, відбувалися в приміщенні. 3 9-ї до 11-ї та 3 15-ї до 17-ї годин тварини перебували на вигульних майданчиках.

Дослідження поведінкових реакцій показали, що найдовше споживають корм тварини першої лактації 3 середньою (від 3-х до 4-х балів) вгодованістю $208,5$ хв, що на 17 хв (P $\geq 0,999)$ довше, ніж тварини 3 вищесередньою вгодованістю, і на 14,5 хв $(\mathrm{P} \geq 0,99)-$ тварини другої лактації (табл. 6).

При цьому найвищий добовий надій - 18,2
18,7 кг був у групі корів із середньою (від 3-х до 4-х балів) вгодованістю, а у групах корів вищесередньої вгодованості він складав 17,1 та 17,2 кг відповідно.

Щодо показника відпочинку лежачи, то тільки група корів першої лактації з вгодованістю від 3-х до 4-х балів вірогідно $(\mathrm{P} \geq 0,999)$ перевищувала показник тварин у групі 3 вгодованістю 4 і більше балів на 15 хв, а відпочинку стоячи $(\mathrm{P} \geq 0,95)$ - менше на $12,5 \times$ хв.

Дослідження, проведенні в умовах добровільного вигулу, показали, що показники руху в групі корів 3 вгодованістю 4 і більше балів були вищими проти показників корів середньої вгодованості на 19,5 і 6,5 хв $(\mathrm{P} \geq 0,95)$.

Аналізуючи етограму дійних корів першої лактації бачимо, що основні показники добової поведінки перебувають в рекомендованих межах (рис. 3). 
Таблиця 6

Кормова поведінка корів різної вгодованості

\begin{tabular}{|c|c|c|c|c|}
\hline \multirow{3}{*}{ Показник } & \multicolumn{2}{|c|}{ Перша лактація, $\mathrm{n}=39$} & \multicolumn{2}{|c|}{ Друга лактація, $\mathrm{n}=42$} \\
\hline & \multicolumn{2}{|c|}{ Група корів за вгодованістю, балів } & \multicolumn{2}{|c|}{ Група корів за вгодованістю, балів } \\
\hline & від 3 до 4 & 4 і більше & від 3 до 4 & 4 і більше \\
\hline $\mathrm{n}$ & 25 & 14 & 29 & 13 \\
\hline Середньодобовий надій, кг & $18,2 \pm 0,58$ & $17,1 \pm 0,49$ & $18,7 \pm 0,50$ & $17,2 \pm 0,42 *$ \\
\hline Поїдання кормів, хв & $208,5 \pm 2,83$ & $191,5 \pm 3,14 * * *$ & $223,5 \pm 2,49$ & $209,0 \pm 3,12 * *$ \\
\hline Відпочинок на ногах, всього, хв & $144,0 \pm 3,02$ & $156,5 \pm 3,60^{*}$ & $141,0 \pm 2,81$ & $143,0 \pm 3,25$ \\
\hline у тому числі жуйка, хв & $90,5 \pm 3,46$ & $99,5 \pm 3,63$ & $93,5 \pm 2,08$ & $96,0 \pm 3,02$ \\
\hline Відпочинок лежачи, всього, хв & $238,0 \pm 2,24$ & $223,0 \pm 3,06^{* * *}$ & $230,0 \pm 3,23$ & $236,0 \pm 2,69$ \\
\hline у тому числі жуйка, хв & $179,5 \pm 2,88$ & $161,5 \pm 3,14 * * *$ & $175,0 \pm 2,48$ & $177,5 \pm 2,74$ \\
\hline Жуйка, всього, хв & $270,0 \pm 5,15$ & $261,0 \pm 4,70$ & $268,5 \pm 4,16$ & $273,5 \pm 5,21$ \\
\hline Рух на вигульному майданчику, хв & $129,5 \pm 5,58$ & $149,0 \pm 4,28 *$ & $125,5 \pm 2,14$ & $132,0 \pm 2,85^{*}$ \\
\hline
\end{tabular}

Примітки: * $\mathrm{P}>0,95 ; * * \mathrm{P}>0,99 ; * * * \mathrm{P}<0,999$ супроти групи корів середньої вгодованості

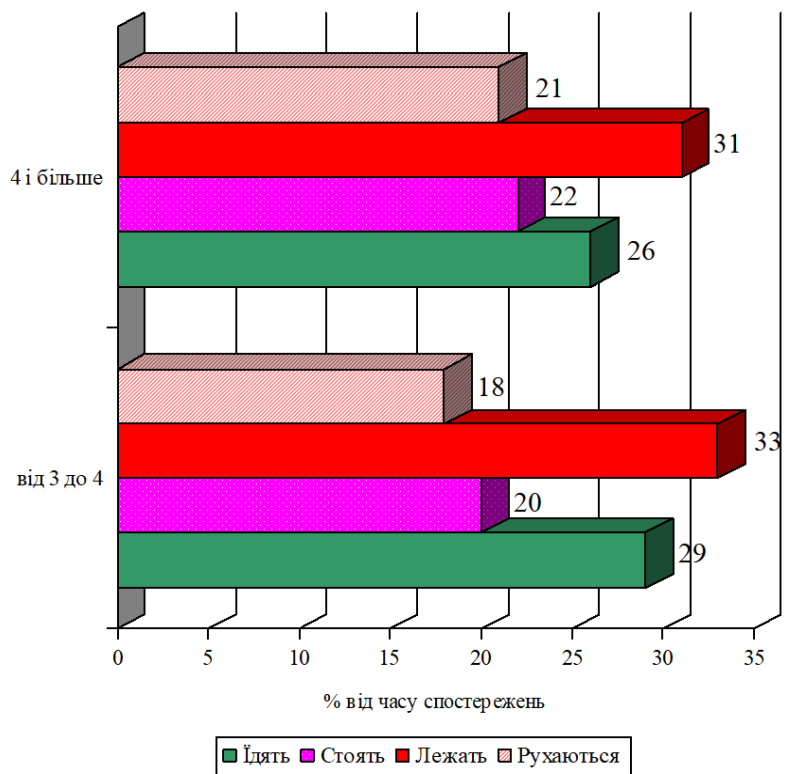

Рис. 3. Співвідношення затраченого часу на окремі елементи поведінки корів першої лактації

Встановлено, що найдовше споживають корм тварини першої лактації з середньою (від 3-х до 4-х балів) вгодованістю - $29 \%$ загального часу спостережень (720 хв), що на $3 \%$ довше супроти показника тварин вищої вгодованості (4 і більше балів). При цьому тварини в середньому витрачали на відпочинок у положенні лежачи - $18 \%$, стоячи - $20 \%$, на рух $18 \%$.

Аналіз тривалості поведінкових реакцій корів другої лактації показав, що найдовше акт дії поїдання кормів тривав у корів із вгодованістю від 3 до 4 балів і становив $31 \%$ загального часу (720 хв) (рис. 4).

Щодо поведінки дійних корів другої лактації, найдовше (33\%) відпочивали лежачи корови, оцінені від 4 і більше балів за вгодованістю. За даної вгодованості тварини більше часу витрачали на рух (18 \%) і менше на поїдання кормів.

Встановлена залежність вгодованості корів та продуктивності з кормовою активністю, що підтверджує основний висновок про необхідність оцінки і врахування перших двох параметрів при формуванні технологічних груп.

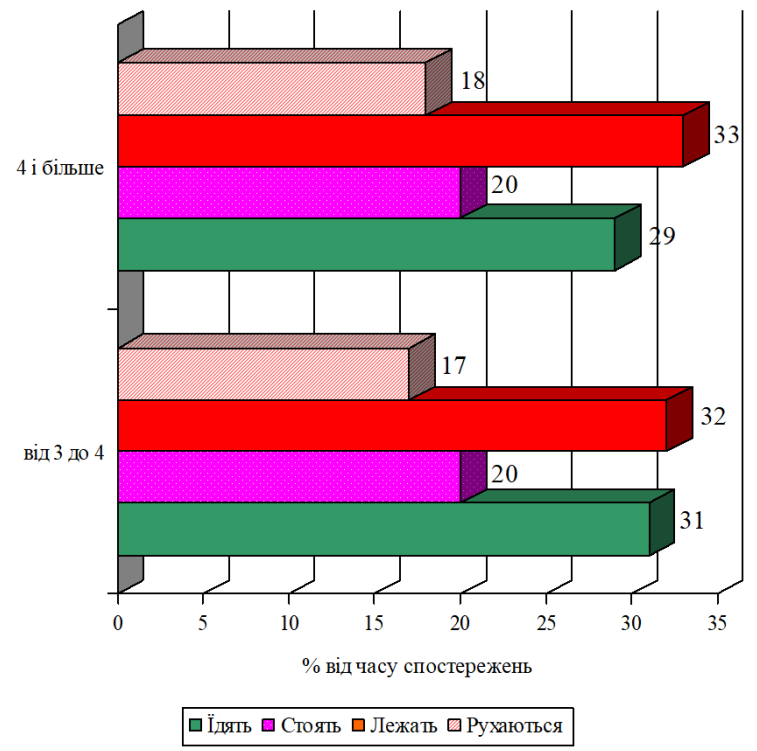

Рис. 4. Співвідношення затраченого часу на окремі елементи поведінки корів другої лактації

Розрахунками встановлено, що враховуючи вгодованість корів, найбільший прибуток на одну корову був отриманий від тварин середньої вгодованості та становив 3,8 тис. грн за першу лактацію, 4,3 тис. грн - за другу. Даний показник перевищував прибуток, отриманий від утримання корів вищої вгодованості, на 7,9 \% відповідно.

\section{Висновки}

Серед корів першої лактації найбільшу частку становили корови з середньою вгодованістю (від 3-х до 4-х балів) і складали 25 голів (64\%), а корів вищесередньої вгодованості (4 і більше балів) - 14 голів (36\%). Найвища молочна продуктивність у корів першої лактації встановлена у групі за вгодованістю від 3 до 4 балів, що на 9,2\% (P $\geq 0,99)$ більше, проти показника групи корів із вгодованістю 4 бали і більше. У корів другої лактації надої групи із вгодованістю від 3 до 4 балів перевищували надої корів із вгодованістю 4 бали і більше на $12,9 \%$ (P $\geq 0,95)$. Найвищі середньодобові надої за першу лактацію встановлено у групах середньої вгодованості, що залежно від мі- 
сяця на 5,5-11,7 \% (P $\geq 0,95-\mathrm{P} \geq 0,999)$ більше проти показника групи корів вищої вгодованості, корів другої лактації - на 6,9-10,0 \% (P $\geq 0,95-\mathrm{P} \geq 0,999)$ відповідно.

За перебігом лактації корів української чорнорябої молочної породи, яких оцінено у 4 і більше балів за вгодованістю, можна зарахувати до типу корів з високою і сталою продуктивністю та рівномірним перебігом лактації. Корів, що оцінили за вгодованістю від 3-х до 4-х балів, до тих, які відразу після отелення проявляють високу продуктивність, що згодом різко знижується, лактаційна крива після короткочасного руху вгору швидко спадає.

Постійність лактаційних кривих була вищою у корів вищої вгодованості супроти показника корів середньої вгодованості. Встановлено, що найдовше споживають корм тварини першої лактації з середньою вгодованістю - $29 \%$ загального часу спостережень (720 хв), що на $3 \%$ довше супроти показника тварин вищої вгодованості, другої лактації - 31 \%.

Перспективи подальших досліджень полягають у визначенні взаємозв'язку тривалості лактації корів із показниками відтворювальної здатності залежно від лактації.

\section{References}

Berry, D., Buckley, F., Dillon, P. et al. (2003). Genetic parameters for body condition score, body weight, milk yield, and fertility estimated using random regression models. Journal of Dairy Science, 86, 3704-3717. doi: 10.3168/jds.S0022-0302(03)73976-9.

Bilchenko, H. (2011). Vplyv hodivli na vidtvorennia stada. Ahroekspert, 11(40), 91-95 (in Ukrainian).

Borshch, O. O. (2016). Rol faktoru vhodovanosti za riznykh tekhnolohii utrymannia $\mathrm{v}$ realizatsii produktyvnoho potentsialu molochnoi khudoby. Avtoreferat dysertatsii na zdobuttia naukovoho stupenia kandydata silskohos-podarskykh nauk 06.02.04 - tekhnolohiia vyrobnytstva produktiv tvarynnytstva Dnipropetrovsk (in Ukrainian).

Borshch, O. O., Borshch, O. V., \& Liskovych, V. A. (2016). Etolohichni osoblyvosti diinykh koriv riznoi vhodovanosti $\mathrm{V}$ umovakh robotyzovanoi fermy. Tekhnolohiia vyrobnytstva i pererobky produktsii tvarynnytstva, 1, 5-9. URL: http://rep.btsau.edu.ua/ handle/BNAU/715 (in Ukrainian).

Chernenko, O. M., Chernenko, O. I., Shulzhenko, N. M., \& Bordunova, O. G. (2018). Biological features of cows with different levels of stress resistance. Ukrainian Journal of Ecology, 8(1), 466-474. doi: 10.15421/2018 237.

Cherniavska, T. O. (2018). Vyvchennia zviazku mizh pokaznykamy molochnoi produktyvnosti koriv ukrainskoi cher-vono-riaboi molochnoi porody. Visnyk Sumskoho natsionalnoho ahrarnoho universytetu, 7(35), 187-195. URL: http://repo.snau.edu.ua/bitstream/ $123456789 / 6605 / 1 / 7 . p d f$ (in Ukrainian).

Dubin, A. M., \& Volenko, I. S. (2005). Rekomendatsii po otsintsi koriv molochnykh porid za vhodovanistiu. Kyiv (in Ukrainian).
Edmonson, A. J., Lean, I. J., Weaver, L. D. et al. (1989). A body condition scoring chart for Holstein dairy cows. Journal of Dairy Science, 72, 68-78. doi: 10.3168/jds.S0022-0302(89)79081-0.

Havrylenko, M. S., Savchuk, D. I., \& Hnoievyi, V. V. (1994). Otsinka vhodovanosti molochnoi khudoby za balnoiu shkaloiu. Metodychni rekomendatsii. K.: Ukr INTEI (in Ukrainian).

Herlihy, M. M., Berry, D. P., Crowe, M. A. et al. (2011). Evaluation of protocols to synchronize estrus and ovulation in seasonal calving pasture-based dairy production systems. Journal of Dairy Science, 94, 4488-4501. doi: 10.3168/jds.2010-4126.

Iaremchuk, O. S., \& Hotsuliak, S. V. (2019). Adaptatsiia koriv ukrainskoi chorno-riaboi molochnoi porody do umov promyslovoi tekhnolohii. Ahrarna nauka ta kharchovi tekhnolohii, 1, 146-153 (in Ukrainian).

Iasevin, S. Ye. (2011). Otsinka ta udoskonalennia intensyvnoi tekhnolohii vyrobnytstva moloka: avtoref. dys. ... kand. s.-h. nauk. Mykolaiv (in Ukrainian).

Lukhtai, A. M. (2009). Kharakter povedinky koriv ukrainskoi chervono-riaboi porody u riznykh za rozmirom tekh-nolohichnykh hrupakh. Tavriiskyi naukovyi visnyk, 64(3), 232-236 (in Ukrainian).

Minviel, J. J., \& Latruffe, L. (2017). Effect of public subsidies on farm technical efficiency: a meta-analysis of empirical results. Applied Economics, 49(2), 213226. doi: 10.1080/00036846.2016.1194963.

Mylostyvyi, R., \& Chernenko, O. (2019). Correlations between Environmental Factors and Milk Production of Holstein Cows. Data, 4(3), 103. doi: $10.3390 /$ data4030103.

Mylostyvyi, R., Chernenko, O., \& Lisna, A. (2019). Prediction of comfort for dairy cows, depending on the state of the environment and the type of barn. Development of Modern Science: The Experience of European Countries and Prospects for Ukraine, 394-410. doi: 10.30525/978-9934-571-78-7 53.

Petrenko, V. I. (2003). Efektyvnyi sposib vyznachennia kondytsii koriv. Ahrarna nauka vyrobnytstvu: nauk.inform. biul. zavershenykh nauk. rozrobok, 3, 8-12 (in Ukrainian).

Plotnikov, V. P., \& Chuchunov, V. A. (2007). Vlijanie aktivnogo povedenija korov na kachestvennye pokazateli mo-loka. Izvestija Nizhnevolzhskogo agrouniversitetskogo kompleksa: nauka i vysshee professional'noe obrazovanie, 12, 17-19 (in Russian).

Podobed, L. I., Rudenko, E. V., \& Giska, V. V. (2009). Racional'naja, dostatochnaja i jekologicheski sbalansirovan-naja sistema kormoproizvodstva. Odessa (in Russian).

Shcherbatyi, Z. Ie., Bodnar, P. V., \& Kropyvka, Yu. H. (2017). Molochna produktyvnist ta vidtvorna zdatnist koriv ukrainskoi chorno-riaboi molochnoi porody riznykh typiv konstytutsii. Naukovyi visnyk Lvivskoho natsionalnoho universytetu veterynarnoi medytsyny ta biotekhnolohii imeni S.Z. Gzhytskoho, 19(74), 182-187. doi: 10.15421/nvlvet7440 (in Ukrainian).

Shkurko, T. P. (2009). Produktyvne vykorystannia koriv molochnykh porid: monohrafiia. Dnipropetrovsk, IMA-Pres (in Ukrainian). 
Tarasova, Yu. A. (2017). Stan ta perspektyvy rozvytku molochnoi haluzi Ukrainy. Visnyk sotsialnoekonomichnykh doslidzhen, 1(62), 149-156. doi: 10.33987/vsed.1(62).2017.149-156 (in Ukrainian).
Tkachuk, V. P., Shuliar, A. L., \& Shuliar, A. L. (2016). Otsinka vplyvu henotypovykh ta paratypovykh faktoriv na molochnu produktyvnist koriv ukrainskoi chornoriaboi molochnoi porody. Biolohiia tvaryn, 18(4), 193 (in Ukrainian). 